\title{
Raising awareness in teacher education: from the EFL course book to other ELF-aware
}

\section{sources}

\author{
Sensibilização para a formação de professores: do livro do curso EFL para outras fontes \\ conscientes do ELF
}

\author{
Lili Cavalheiro* \\ Universidade de Lisboa \\ Lisboa, Portugal
}

\begin{abstract}
Resumo: Atualmente o inglês funciona como uma língua franca global cuja comunicação é maioritariamente feita entre falantes não-nativos. Apesar desta realidade, o ensino do inglês e os materiais didáticos utilizados continuam a seguir essencialmente não só o inglês padrão como também os paradigmas culturais da Inglaterra e dos Estados Unidos da América. Apesar dos professores de inglês como língua estrangeira (ILE) estarem atentos ao uso internacional da língua, a maioria continua a seguir o modelo padronizado apresentado nos manuais escolares utilizados nas escolas sem qualquer tipo de questionamento sobre a língua, cultura ou até as imagens presentes nesses manuais. Tendo em conta esta realidade, é importante que os professores de ILE aprendam desde logo a tomar uma posição mais crítica e, por isso, os cursos de formação de professores são o lugar ideal para que os futuros professores de inglês conheçam como podem tomar uma perspectiva mais crítica ao analisarem os manuais escolares a adoptar nas suas aulas. Através desta reflexão conseguem tomar uma decisão mais informada e perceber aquilo que mais interessa para os seus alunos. Paralelamente, poderão também aprender a desenvolver os seus próprios materiais, indo ao encontro das necessidades e dos interesses da turma, o que lhes permite também criar materiais que reflitam o uso global da língua. Por fim, este artigo apresenta algumas sugestões sobre como os professores podem desenvolver materiais que espelham o uso atual da língua inglesa.
\end{abstract}

Palavras-chave: Ensino da língua inglesa. Inglês como língua franca. Materiais de ensino. Formação de professores.

\begin{abstract}
English is currently a global lingua franca, through which communication mainly takes place between non-native speakers of the language. Despite this reality, English Language Teaching (ELT) and ELT materials have continued to mainly follow the Standard English and British/American cultural paradigms. As a result, even though English as a Foreign Language (EFL) teachers may be aware of the international use of the language, the majority continue to blindly follow the models presented in the course books used in schools, without ever questioning the language, culture or even images that are depicted. Bearing this in mind, this paper proposes that it is crucial that EFL teachers learn how to take a critical stance from early on; therefore, preservice teacher education programs are viewed as the essential place for future EFL teachers to learn how to critically analyze course books. By doing so, they can take an informed stance on what matters most for their class and be able to develop their own materials that may be more in line with the students' interests/needs, as well as reflect the global use of English. Finally, this paper ends with some suggestions on how teachers can develop more globally-oriented materials that reflect the actual use of English.
\end{abstract}

Keywords: English Language Teaching. English as a Lingua Franca. Teaching Materials. Teacher education.

* Professora do Centro de Estudos Anglísticos da Universidade de Lisboa/Universidade de Lisboa. Email: lilicavalheiro@campus.ul.pt. 


\section{INTRODUCTION}

Communication in English nowadays mostly takes place between non-native speakers (NNS) of the language, who share English as their common language of choice to communicate in a number of fields (e.g. business, tourism, academia, social media, sports). In fact, this widespread use of English, not only among NNSs (from the Expanding circle), but also across Inner and Outer circle countries (KACHRU, 1985), has contributed to the increasing role of English as a lingua franca or international language. As a result of this, Matsuda (2017) argues that this global use of English has obviously also brought about challenges for English language teaching (ELT):

the unprecedented spread of English and the growing importance of English as an International Language (EIL) have complicated the notion of English, English speakers and English-speaking culture, and challenged the taken-for-granted assumptions in the field of English language teaching (ELT) (MATSUDA, 2017, p. xiii).

Although Matsuda, as well as other scholars (e.g. ALSAGOFF et al., 2012; BAYYURT \& SIFAKIS, 2015) recognize the 'challenges' ELT faces, many English as a Foreign Language (EFL) teachers continue to follow the traditional EFL models with which they were brought up in. It is not that they are unaware of the current global role of English, but rather that they are unacquainted with how to apply a more international perspective within their classroom.

In addition, the fact that publishers have come to provide ready made teaching packs for teachers, consisting of student course books, teacher books, USB flash drives, DVDs, CDs, among other materials, has also contributed to teachers accepting what is given to them without ever questioning the language, culture or even images that are depicted in these materials. It is this issue that this paper alerts to; the fact that EFL teachers need to take on a more critical stance towards the materials that are provided in schools or that they develop themselves.

Therefore, after considering the current global role of English and traditional EFL practices and materials (e.g. course books), this paper focuses on how essential it is for teachers to learn how to take a critical stance from early on in their teaching practice. Bearing this in mind, pre-service teacher education programs are presented as the essential place for future EFL teachers to acquire the necessary skills and know-how on how to critically analyze, in this specific case, the materials that may be presented to them in schools (e.g. course books). By doing so, they can take an informed stance on what matters most for their class, and be able to develop their own materials/activities that are more in line with their students' interests/needs, as well as reflect the global use of English.

This paper finally ends with some suggestions of (audio)visual resources as well as websites/apps for teachers to develop more ELF-aware teaching materials/activities that 
not only reflect the current use of English, but that are also in keeping with their needs and interests.

\section{THE CURRENT ROLE OF ENGLISH}

Although Mandarin has more native speakers (NSs) than English, "it is English that is considered the international language of the world today" (MCKAY \& BOKHORSTHENG, 2008, p. 19). In fact, already in 2006, Kachru mentioned that the estimate of users of English worldwide varied between one billion and two billion, and the tendency has been for these numbers to rise. However, simply taking numbers into consideration alone "does not give us a sense of how globally spread the language is" (MATSUDA, 2012b, p. 1 ); what really matters is the 'special role' (MATSUDA, 2012b) it acquires in countries where it is spoken not only by a large number of NSs (e.g. Inner circle countries), but also far beyond that (e.g. Outer and Expanding circle countries, and diverse multinational contexts).

In the case of English, its international status mainly lies on the number of second language speakers, who have contributed not only to the geographical spread of the language, but also to the significance attributed to it, namely in the fields of economics (e.g. transnational corporations, outsourcing), education (e.g. educational institutions, government policies) and the mass media (e.g. electronic communication, movies, advertising, music). In other words, the current global role of English is essentially based on the communication and interaction it foments among different people from varied national, cultural and linguistic backgrounds.

As a result of this widespread use, English has played "an essential role in creating a common voice shared by the great majority of the world's population" (CAVALHEIRO, 2013, p. 8). This, however, does not suggest the existence of a single intelligible global variety that can be used to communicate successfully in every international scenario. Instead, emphasis is placed on the different Englishes spoken, and how these can be adapted and molded towards a competent use of the language, by resorting to a variety of communication strategies (MATSUDA, 2012b). By doing so, not only is mutual intelligibility being promoted, but so is effective communication.

In this sense, it can be argued that English takes on the role of a lingua franca (ELF) or international language (EIL), both terms being used interchangeably. In the case ELF, Seidlhofer (2011) refers to it as "any use of English among speakers of different first languages for whom English is the communicative medium of choice, and often the only option" (p. 7). Jenkins et al. (2011), however, goes even further and mentions that

[ELF users are] highly skilled communicators who make use of their multilingual resources in ways not available to monolingual NSEs [native speakers of English], and who are found to prioritize successful communication over narrow notions of 'correctness' in ways that NSEs, with their stronger attachment to their native English, may find more challenging (JENKINS et al., 2011, p. 284). 
Bearing in mind these issues, it may be concluded that ELF is defined functionally in relation to its use in intercultural interactions, as opposed to formally regarding its reference to NS norms. Similarly, Friedrich and Matsuda (2010) also refer to EIL as a function that English carries out in global multilingual scenarios. In these situations, speakers are able to use several strategies to negotiate, not only linguistic variations, but also other differences, so as to communicate effectively in an intelligible manner.

Considering then the current role of English, it is evident that there will be certain implications when comparing the type of English that has been traditionally presented in EFL-classrooms, and its actual use outside school. Not only will this issue affect conventional teaching practices, but also the teaching materials presented, two issues that are taken into consideration in the following section.

\section{ELT PRACTICES AND TEACHING MATERIALS: FROM EFL TO ELF}

Teaching English within the EFL context has conventionally been associated with a static view of the language, which is centered on NSs from the Inner circle. Attention has particularly laid on Standard English, more specifically on one of the two most notable varieties, Standard British English (in the case of Europe) or General American English, and associated with each variety, is the conventional notion of culture (e.g. Big Ben and the Royal family, and the Statue of Liberty, respectively) (CAVALHEIRO, 2015).

Along with these practices centered on a NS model, teaching materials have likewise portrayed a NS-based view of language and culture, in particular course books from internationally renowned publishers (and from national publishers as well). The reason for this lies on the initial need that there was in ELT to establish a stable basis, which also simultaneously brought the demand for more efficient and suitable teaching materials. The support from publishing houses played (and continues to play) a major role in sustaining the ELT profession with a variety of publications directed at students as well as teachers. In the 1930's, for instance, publishing houses such as Green (until the 1960's), Longman and Oxford University Press began to put into circulation ELT textbooks as well as continuing series, having maintained since then their leadership in the global ELT market. In addition, other companies worth mentioning include Macmillan and Cambridge University Press, which despite having entered this market more recently, have equally played an important role. Over the years, these publications have had an impact on the dissemination of a particular view of the English language and culture, having contributed to an imbedded interpretation of what ELT should be like, not only on the part of teachers, but also of students, their parents, materials developers, policy makers, and so on.

However, the supposition that English language learners acquire English to interact with NSs is only part of the reality, therefore, a pedagogy that is simply centered on Standard English varieties as well as on the people and culture of Inner circle countries is currently regarded as insufficient. 
In recent years, several have been the studies, conferences, workshops and publications, for instance, which have explored the use of EIL/ELF and its implications for teaching. As Jenkins et al. (2011) state, "ELF empirical work and theoretical discussions have raised profound questions about current principles and practice in ELT" (p. 304).

McKay (2002), for instance, emphasizes the specific need for English to be considered differently when in comparison to the learning/teaching of other second or foreign languages. As she argues, "the teaching and learning of an international language must be based on an entirely different set of assumptions than the teaching and learning of any other second or foreign language" (MCKAY, 2002, p. 1). The issue that remains though is that when traditional practices and ways of thinking are put into question, like in McKay's case, teachers do not always wholeheartedly accept these 'challenges'. As Jenkins et al. (2011, p. 305) reiterate, "because ELF research findings pose substantial challenges to current beliefs and practice, it is likely that further engagement with ELF in the language classroom will be contested and hence gradual."

In order to prepare successful language users for international communication, it is necessary then that there be substantial changes in teachers' and learners' mindsets (e.g. MCKAY \& BOCKHORST-HENG, 2008; SHARIFIAN, 2009). In this sense, it is important that both groups realize that English language use in the last few decades has mainly been centered on international communication among those who do not have English as their L1, and who mainly use it as a lingua franca. Only this way will these groups start to question the validity of simply imitating NS norms as a guarantee for effective communication (JENKINS 2000, 2002). By viewing NS norms as no longer the only beacon guiding learners to attain successful communicative competence, other modified forms of English can be viewed as both legitimate and enhancing in terms of functional range (rather than restricted or inferior, in the case of an EFL-approach), and users can finally communicate more freely without sticking to specific linguistic and/or sociocultural norms.

However, once again, this is only pedagogically conceivable if adjustments are made in a variety of areas, namely with teachers, course objectives, curriculum design, teaching materials and even assessment.

In the case of teaching materials, and considering ELT course books in specific, Siqueira (2015, p. 241) mentions "it is departing from them and working with them that a lot is done in language teaching and learning." In fact, in many classrooms the course book is the main source of both linguistic and cultural input for learners. As Richards (2002) mentions, "much of the language teaching that occurs throughout the world today could not take place without the extensive use of commercial textbooks" (p. 26). In addition to course books being seen as a key element in many language courses, they are also the main source for language input and language practice in classrooms, the basis for the content developed in class, a supplement for educators' teaching, a major source of contact with the language, as well as a form of teacher training (especially for less 
experienced teachers, as they provide ideas to plan and teach lessons) (RICHARDS, 2002).

There are also obviously other advantages and disadvantages associated with course book use, which need to be mentioned (RICHARDS, 2002). In the former case, for example, they offer structure and syllabus for programs, they contribute to standardizing instruction, they provide quality, they offer a range of learning resources, they present real language models and input, as well as the fact that they are usually visually attractive. In the latter case, some of the potential negative aspects of course books may be that some comprise inauthentic language not typical of real language use, content may be misleading or distorted (many times an idealized view of the world is depicted), it may not be in line with learners' interests and needs, or it may even 'deskill' teachers, who merely become a "technician whose primarily function is to present materials prepared by others" (RICHARDS, 2002, p. 2).

In addition, and still in relation to the issue of content, Siqueira (2015) further criticizes how course books have given rise to a 'harmless' 'plastic world' (SIQUEIRA, 2010) that neutralizes any controversial issues. As Siqueira mentions, the notion of family, for instance, many times continues to be portrayed as a conventional middle-class family consisting of a mother, father and two children (boy and girl), excluding other nuclear family units, such as single or homosexual parents. Other issues related to politics, alcohol, religion, narcotics or 'isms' (e.g. ethnocentrism, racism, sexism) are viewed as being taboo and, therefore, are largely avoided in classes, even though they "could foster the development of critical awareness on the part of teachers and students" (SIQUEIRA, 2010, p. 231 apud SIQUEIRA, 2015, p. 247).

Yet another issue that may also be put in question in course books, as Jenkins (2012, p. 487) emphasizes, is the fact that "there are few examples [...] that adopt a more ELForiented approach, or at least NNES [Non-native English speaker]-oriented approach", and that learners continue to be "encouraged to aim for the kind of English that British and North American English speakers use among themselves."

On a similar note, Siqueira (2015) later goes on to mention how ELT materials, in general, continue to neglect the existent variety in English language use, being it many times perceived as a 'secondary issue':

The world consumes English, it appropriates English, provides English with new colors, new flavors, new forms and perspectives to exactly see the world. However, this very same world continues being weakly represented in all sorts of ELT materials. In other words, it seems that the extent of the diffusion of English geographically, the enormous cultural diversity of the speakers who use it as a lingua franca, the infinitely varied domains in which language is found, and the purposes it serves (Dewey, 2006) remain a secondary issue to the ELT industry (SIQUEIRA, 2015, p. 251).

In keeping with Jenkins' and Siqueira's arguments, other recent research has not only indicated that ELF is for the most part underrepresented in course books, but in other web-based teaching materials as well (e.g. MATSUDA, 2012a, VETTOREL \& 
LOPRIORE, 2013). In addition to this, there is also the issue of a general absence of properly designed ELF-aware teaching materials (SEIDLHOFER, 2011, SIFAKIS, 2009).

In view of this, Lopriore and Vettorel (2015) urge that there be a more up to date outlook in both classroom practices and didactic materials, therefore contributing to a greater awareness, sensitivity and respect regarding language differences (CAVALHEIRO \& GUERRA, forthcoming). In order for this to happen though teachers should be able to switch from traditional EFL to more ELF-aware classes as gradually and naturally as their setting permits (SIFAKIS, 2009); hence averting deviations from the EFL curriculum in question, while still promoting a more ELF-aware angle in the implemented ELT syllabus.

If learning how to use and adapt course books, as well as develop original ELFaware teaching materials is viewed as an integral part of teachers' professional knowledge, the question that remains is: when and where do teachers gain such knowledge? The answer may lie in teacher education, preferably pre-service teacher education programs, where future language teachers acquire not only theoretical input at universities, but also the opportunity to put into practice that knowledge throughout their practicum in primary/secondary schools with their students. It is this precise issue that the following section will take a look at - how teacher education programs play a critical role in raising ELF-awareness.

\section{RAISING ELF-AWARENESS IN TEACHER EDUCATION}

Seeing as pre-service teacher education combines both a theoretical academic perspective with a practical teaching experience, this seems like the ideal place to encourage discussions among trainees, cooperating teachers and university professors on a variety of matters, such as language syllabus, teaching materials, approaches and methods, language assessment and finally, one's own knowledge base (JENKINS et. al., 2011), all of which have far reaching implications in language teacher education.

Before delving into the notion of raising ELF-awareness in these programs, it is worth reflecting on what the 'teacher education' implies. As it is indicated in the name, particular attention should be given to the education and development of future teachers, and not only to their training. According to Richards and Farrell (2005), training is restricted to the fundamental principles and techniques that future teachers need to acquire in order to apply them afterwards. Development, on the other hand, has a more long-lasting effect, in which understanding, examination and reflection are vital issues for (future) teachers to acquire; hence contributing to their perception of teaching and of their role as teachers.

On a similar note, Widdowson (1990) also refers to how training is connected with finding answers and solutions to predetermined issues, while development entails reformulating ideas and adapting mindsets to the different situations that may emerge. As he argues: 
[Training] is directed at providing solutions to a set of predictable problems and sets a premium on unreflecting expertise [contrastingly, education] provides for situations which cannot be accommodated into preconceived patterns of response but which require a reformulation of ideas and the modification of established formulae (WIDDOWSON, 1990, p. 61).

Considering the distinction established between these two concepts, if change is to be implemented in teacher education, it is clear then that it should be via 'development', rather than through 'training'. In other words, student teachers need to go beyond a simply critical perspective, so as to assume a more transformative one (SIFAKIS 2014a). Even though the former may be considered an umbrella term that comprises the latter because of the common element of reflection - both are different. While a critical perspective is more outwardly centered and tries to grasp and transform a particular context, a transformative perspective is more focused on looking inwards, trying to understand and change a person.

Bearing this in mind, rather than being prepared for a certain set of pre-formulated teaching methods, student teachers should have a more extensive education, in which they are able to measure the implications of ELF use in their own settings, and to adjust their teaching to students' particular needs. According to Seidlhofer (2004), teacher education is therefore imperative, particularly when ELF-related issues, like the importance of language variation, identity and intercultural communication across different educational contexts, are going to be reconsidered:

Such teacher education would foster an understanding of the processes of language variation and change, the relationship between language and identity, the importance of socialpsychological factors in intercultural communication and the suspect nature of any supposedly universal solutions to pedagogic problems (SEIDLHOFER 2004: 228).

In this sense, student teachers are not merely sponges absorbing information, but rather conscious individuals learning how to become 'autonomous practitioners' capable of making 'informed decisions' in their everyday ELT practices. As Bayyurt and Sifakis (2017) argue:

Teachers are not just passive receivers of knowledge and skills, but rather they are expected to be autonomous practitioners who are able to make informed decisions about virtually all aspects of teaching, from researching and responding to their learners' individual needs to selecting and/or adapting courseware to applying appropriate assessment and testing techniques (BAYYURT \& SIFAKIS, 2017, p. 4).

By taking on a more reflective and critical perspective, student teachers obtain not only an "essential understanding of the nature of language and its use" (SEIDLHOFER, 2011, p. 204), but also the knowledge that will support their pedagogic practices, and enhance their status as well-informed and self-reliant professionals. 
The dilemma that persists is: "ELF is new just like Cubism was new. It's really difficult to convince people that ELF is appropriate, that it's fine, that it's beautiful" (SIFAKIS, 2014c). The reason for this may largely be because of 1) the challenges associated with ELF because it is relatively recent; 2) its application in classrooms, since it takes on a different point of view when analyzing and theorizing about the spread of the language and teachers' attitudes about Standard English; and 3) contradictory opinions about the status of NNS interactions and their intelligibility, seeing as ELF distances itself from EFL (BAYYURT \& SIFAKIS, 2017).

So what can be done then in order to raise ELF-awareness in the classroom? Bayyurt and Sifakis (2017) refer to a model that is divided into three stages and which promotes EIL-aware teacher education, a vital issue worth exploring from early on with pre-service teachers. The aim of this model is not to indoctrinate (future) teachers, but instead, to focus on teacher development, and give them the opportunity to grow both individually and professionally.

Taking a look at each of the stages separately, the first stage of the model is centered on ELF/EIL exposure; in other words, showing student teachers how English has spread throughout the globe and how extensive communication in English is in today's globalized world. In order to grasp the full extent of this, it is imperative to demonstrate how English interactions can be successful, in all their multiplicity and complicatedness. Examples of effective exchanges between NNSs should be given, but student teachers can participate too with other speakers (native or non-native), so as to gain hands-on experience of language contact and negotiation.

As for the second stage, the aim is to raise critical awareness; in other words, making student teachers aware of the impact of the challenges felt before in their own teaching environment, and how can they be considered in a critical and practical way. As Bayyurt and Sifakis (2017) go on to mention, the critical awareness developed can be both external and internal. In the former case, attention is given to developing student teachers' perception of the global spread of English, while in the latter case, stress is placed on exploring student teachers' more profound beliefs regarding both communication and teaching. In the end, both external and internal critical awareness will have a clear influence on the decisions that are made, such as to what extent teaching practices can be adapted or even changed towards a more ELF-aware approach.

Lastly, the third stage focuses on the action plan, which is divided into three parts. First, student teachers have the opportunity to select and incorporate the ELF elements they believe are important for their learners and design their own instructional activities accordingly. Then they teach their lessons, and afterwards, these lessons are evaluated (either individually or in groups), so as to reflect on their own perception of ELF and the situation of their teaching environment.

With this model emphasis is set on teacher development, where student teachers are given the opportunity to reflect on key issues, become conscious of their deeper convictions (which may have never been put into question before), change or not their beliefs according to their will or context, understand the implications of such construct 
in their own teaching environments and apply such construct according to their beliefs or context.

Bearing this in mind and as previously mentioned, by implementing such model, student teachers are able to grow both personally and professionally. At a personal level, they "become conscious of, challenge and perhaps transform their convictions about communicating in English in today's world" (BAYYURT \& SIFAKIS, 2017, p. 15), while at a professional level they become "fully informed of new developments in using English in today's world [and have] (...) experimented with integrating the EIL/ELF-aware approach $(. .$.$) in their own teaching context" (ibid.). In this sense, they acquire not only$ an additional set of skills, but also feel more empowered as NNS English language teachers in the "post-EFL world" (ibid.).

\subsection{COURSE BOOK ANALYSIS AND MATERIALS DEVELOPMENT IN TEACHER EDUCATION: TOWARDS AN ELF PERSPECTIVE}

The three-stage model presented by Bayyurt and Sifakis (2017) is central for promoting a greater reflection and critical stance in what concerns ELT teaching practices in general, but also in terms of course book analysis and materials development, in particular. In conjunction with their model, "the selection, assessment, revision and operationalization of materials in light of EIL/WE [World Englishes] [also] need to be highlighted", as Dinh stresses (2017, p. 134).

As student teachers become aware of the global spread of the English language (the first stage of Bayyurt and Sifakis' model), it is central that they also take into consideration the implications of the changes English is undergoing when selecting and evaluating ELT materials. It is important that they recognize the existing 'monocentric bias in textbooks' (DINH, 2017) that have often been criticized as being 'idealizing' (BASABE, 2006) or even 'misleading' (ARIKAN, 2005), for instance. For this, textbook evaluation is essential, in which both language and culture are contemplated, and where issues like language variation, multilingualism, (different) cultural roles/representations, diversity of speakers (both NSs and NNSs) and how they are represented, intercultural awareness, and cultural stereotypes, among other related issues, are pondered. In addition to a linguistic and cultural analysis, a more semiotic-oriented evaluation should also be adopted, where texts, tasks and visual aids are reflected upon in conjugation with the rest (WENINGER \& KISS, 2013).

Alongside developing critical awareness in general (the second stage of Bayyurt and Sifakis' model), student teachers should develop as well the necessary skills to critically evaluate course books and make more well-informed decisions in terms of the book they believe is more suitable for their context. This can only be achieved by revising the language and culture represented in them, namely by placing attention on "the function of language, negotiation across cultures, cross-cultural comparison and reflection on students' own culture" (DINH, 2017, p. 138). 
Only afterwards, in the action plan stage (the third stage of Bayyurt and Sifakis' model), are student teachers finally prepared to 1) design their own materials and 2) implement them. In the first case, this may be done by selecting additional resources, developing their own supplementary materials and/or, creating or adjusting already existing activities. By doing so, they are able to take a critical stance and choose which varieties of English their learners should be exposed to, what type of cultural issues may be reflected upon, and how and to what extent intercultural communication can be exercised. In the second case, student teachers can finally put into practice the materials they have developed, either with their fellow colleagues (in 'mock' sessions) or with their own students during the practicum, in order to afterwards critically assess the practicality and applicability of the ELF-oriented materials/activities they have employed.

By going through these different stages, student teachers acquire the knowledge and skills to analytically examine and evaluate the course books with which they may 'have' to work with (many of the times imposed by the schools), as well as how they may expand their practices, by adapting resources or developing their own materials.

The issue that may remain though in many student teachers' minds, and for that matter in in-service teachers' and even in teacher trainers' minds, is: how can ELF-aware teaching materials be developed and where can examples of successful ELF interactions be found? This issue is expanded on in the following section where several practical suggestions are provided and which may be implemented in a various teaching scenarios.

\section{SOME SUGGESTIONS FOR DEVELOPING ELF-AWARE TEACHING MATERIALS}

As future English language educators, it is important that student teachers realize how important it is that they be able "to transition from conventional EFL to ELF-aware lessons as gradually and effortlessly as their context allows (e.g. Sifakis 2009), avoiding divergence from the EFL curriculum, but still enhancing the implemented ELT syllabus" (CAVALHEIRO \& GUERRA, forthcoming). As was previously discussed, the objective is not to substitute EFL, but rather to measure to what extent the existing ELT syllabus may be 'enhanced' through an ELF perspective.

The Internet and digital media, for instance, have played a key role in bridging distant people and places, while simultaneously disseminating knowledge across the world. In this sense, the World Wide Web has not only contributed to the passive reception of information and knowledge, but it has also contributed to the creation of numerous networks, which allow users to interact and share knowledge at the same time. This rise in the use of the Internet has obviously had a large impact on how the public communicates, but also in education in general, and in ELT, in specific. The reason for this lies on English being used and accepted as the common shared language in most online communication. As a result, many English language learners are simultaneously Internet users, who use the language to communicate with others. Bearing this in mind, 
Ware et al. (2012) argue that ELT obviously needs to be reconsidered in the face of this reality, being communication skills the key factor:

English learners are now seen as global communicators, sharers of local cultures, arbiters of misunderstandings, and valued contributors to a growing global community. Communication skills therefore take on a new importance for English teaching (...), as the Internet provides a social environment that students enter with increasing frequency outside of the classroom (WARE et al. 2012, p. 72).

Considering how the Internet plays a central role in learners' lives and how it is a constantly growing archive where users may both upload and download information, this section will explore how teachers can adapt and create their own ELF-aware teaching materials though the use of the Internet and digital media, as well as through audiovisual materials in general (e.g. films). By doing so, they can create not only up to date materials/activities on current topics, but also capture their learners' attention and interest, by distancing the learning process from more traditional methods the course book and its exercises) and validating at the same time the international use of English. As Ware et al. (2012, p. 77) stress, "the power of digital media in the classroom stems in part from its potential to bridge in-class activities with out-of-class use, to blur the lines between formal instruction and informal learning, and to validate the wide range of registers and uses of English on the global scene."

Seeing as of the variety of materials/activities educators may employ is infinite, the resources presented here are a mere example of what may be explored. In order to help them, in this particular case, only (audio)visual and Internet sources have been considered.

\subsection{AUDIOVISUAL EXAMPLES OF LINGUISTIC AND CULTURAL DIVERSITY}

(Audio)visual materials have been presented in EFL classrooms for a long time; however, the depicted language/culture has usually been based on the standard British/American language/culture. In the majority of the cases, educators seem to have largely neglected, or even rejected, for instance, the possibility of presenting well-known or successful examples of speakers from other Inner, Outer or Expanding circle countries (CAVALHEIRO \& GUERRA, forthcoming).

By presenting audio recordings or videos (e.g. YouTube) with examples of internationally acclaimed actors/actresses, athletes, musicians, models, or even religious leaders or politicians, learners may realize the existing diversity in terms of English varieties and how unnecessary it is, in fact, to 'sound' like a standard native speaker to communicate effectively at an international level. Some examples that may be given include: Javier Bardem, Irrfan Khan, Sofia Vergara, Audrey Tautou or Arnold Schwarzenegger in TV/cinema; Cristiano Ronaldo, Kimi Räikkönen, Rafael Nadal, Usain Bolt or Adriano Souza in sports; Enrique Iglesias, Shakira, Manu Chao or Psy in music; Sara Sampaio, Gisele Bündchen or Irina Shayk in fashion; and António Guterres, Angela Merkel or Emmanuel Macron in politics, and the Dalai Lama or Pope Francis in religion. 
Songs, in specific, are another audio resource that may be explored in the classroom, and in this particular case, learners' listening and comprehension skills may be worked on, especially when taking into account non-standard varieties, ESL varieties and other NNSs singing in English. An example of a song that displays a non-standard variety of English is "Cheap Thrills", by Sia featuring Sean Paul. In this case, Sia is an Australian singer, while Sean Paul, who is a Jamaican reggae and hip-hop singer, participates by singing in Jamaican English. Still referring to Jamaican English, Portuguese artist Richie Campbell (born Ricardo Costa) has become a well-known reggae singer with his songs "I feel amazing" and "That's how we roll" being curious examples of this English variety. Continuing in Portugal, as tribute to David Bowie's recent passing in 2016, Portuguese singer David Fonseca produced an album entitled Bowie 70, where a number of Portuguese artists, some of whom do not usually sing in English (e.g. Camané, António Zambujo, Rui Reninho or Ana Moura), participated by singing several of Bowie's hits. Although their English pronunciation is clear and the lyrics are easy to follow, in some cases, the artists' Portuguese accents are evident; however, seeing as it does not impede listeners' understanding, why shouldn't English songs sung by NNSs be used in the EFL classroom?

As for film, there are many that also depict diverse linguistic varieties and touch upon multicultural issues and their consequences (e.g. stereotyping, miscommunication). Some examples include: In America (2002) directed by Jim Sheridan (story of an Irish family in a multicultural dilapidated neighborhood in New York City); Crash (2004) directed by Paul Haggis (clashes in multicultural issues in Los Angeles); Slumdog Millionaire (2008) directed by Danny Boyle and The Namesake (2006) directed by Mira Nair (India); Hotel Rwanda (2004) directed by Terry George; The Bang Bang Club (2010) directed by Steven Silver (South Africa); or Boy (2010) directed by Taika Waititi and Whale Rider (2002) directed by Niki Caro (New Zealand).

As regards to television, more and more American television series have come to depict the existing linguistic and cultural diversity of society. Several shows go as far as portraying not only how natural code-switching between English and another language is, but also how it is alright to have characters speak English with their own L1 accent. Some examples that may be given include: Flight of the Concords, HBO (2007-2009); Jane the Virgin, CW (2014- ); The Americans, FX (2013- ); Fresh Off the Boat, ABC (2015- ); or Modern Family, ABC (2009-).

Taking into consideration the examples put forth, language teachers have the possibility of complementing the diverse themes of their syllabi with a variety of (audio)visual resources, in which issues, such as multiculturality as well as linguistic diversity could be explored. In this sense, learners gain not only greater insight to how successful communication may be achieved, but also how miscommunication may be avoided. To that end, issues of pronunciation may be studied, as well as how different accommodation skills can be adapted and how meaning is negotiated differently in various situations. 


\subsection{INTERNET SOURCES}

Despite many teachers' hesitations and ambivalences, the Internet is an endless source waiting to be explored with a vast array of examples and tools to be applied in EFL classrooms. In this particular case, the suggestions put forth take into consideration some online archives, digital media and Web 2.0 tools that may help promote greater ELF-awareness in class.

As for online archives, the Internet accommodates several dialects and accents archives that are fairly useful for EFL teachers who wish to develop ELF-based activities with their learners (CAVALHEIRO \& GUERRA, forthcoming). Some of the archives that may be explored for pedagogical purposes include: the IDEA - International Dialects of English Archive (http://www.dialectsarchive.com/), the Speech Accent Archive (http://accent.gmu.edu/) and the VOICE-Vienna-Oxford International Corpus of English, (https://www.univie.ac.at/voice/). Although different, these archives share the fact that their audio files and written transcripts are made available to the public in general. Examples of both NSs and NNSs from different backgrounds and in different situations (some scripted others spontaneous) are represented as well throughout the different archives. Bearing this in mind, similarly to the audiovisual examples previously cited, upon resorting to these archives, language teachers have the opportunity to build their own teaching materials/activities, which allow students to analyze and reflect upon both pronunciation and 'real' language use, namely code-switching, strategies to negotiate meaning and/or accommodation skills.

In terms of the media, EFL teachers have long resorted to newspapers and magazines to display 'authentic texts' based on British and American language and culture; however, with the advent of the Internet, printed media gave way to online media. Despite the change and easy access to more diverse newspapers, magazines and news channels, teachers have, nonetheless, continued to follow a more traditionalist view (e.g. The Guardian, The Times, BBC, The New York Times, Time, CNN). The issue that persists is the need to raise (future) teachers' awareness of other international publications that continue to publish in English, but which retain a different perspective of a story or tell a whole different story by exploring other native and nonnative cultural contexts. Some examples from different regions include: Asia - China Daily (http://www.chinadaily.com.cn/) is a daily newspaper that translates relevant Chinese news into English for an international audience; The Japan Times (http://www.japantimes.co.jp/) is Japan's largest Englishlanguage newspaper; The Times of India (http://timesofindia.indiatimes.com) is an international Indian daily newspaper written in English; The Middle East - Al Jazeera (http://www.aljazeera.com/) is an Arabic news and network channel, comprising a website and TV channel with worldwide news; Africa - AllAfrica.com (http://allafrica.com/) and Africanews (http://www.africanews.com) are websites that gather both news and videos produced across the African continent about all areas of life, like politics, sports and culture; and Europe - Euronews (http://www.euronews.com/) is a European news channel and website that covers both European and world news from 
a pan-European perspective.

Besides newspapers, magazines and television channels, other online sources that may also be explored, are TED Talks and YouTube videos, which contain a vast array of spoken production in English by NSs and NNSs alike. In the former case, TED consists of a global set of conferences on technology, design, scientific, cultural, and academic topics, which may complement many of the issues developed across different English syllabi. The thousands of talks available to view online for free, along with their easily accessible transcripts and subtitles, make for a more personal approach to the many topics developed in class. As for the latter, YouTube is major source for videos and interviews, which demonstrate interactions among both NSs and NNSs. It is an excellent resource to exemplify how communication may easily cross boarders, in which not only linguistic aspects may be analyzed, but also other issues that may indicate and stress what is being said, such as facial expressions and body language.

Finally, taking into account Web 2.0 tools, the possibilities with which teachers may work with are immense and continue to flourish on a daily basis, therefore, requiring constant research to become familiar with what may be more beneficial for students and what, on the contrary, may have ceased to exist, due to the continuous flow of new apps emerging on a regular basis. Only two types of Web $2.0 \mathrm{apps} / \mathrm{software}$ will be here considered. On the one hand, those that allow for text-to-speech or voice recordings; and on the other hand, those that allow collaboration and communication between users.

In the first case, there are several apps that allow users to record their voices and even create avatars, which are able to speak in a variety of English accents. Voki and Tellagami, for instance, are two examples of apps that allow users to create their own avatars, which can speak in a variety of different accents (in the former case, British, American, Australian, Irish, Scottish, Indian or South African English, and in the latter case, in addition to several native English varieties, also English with a Japanese accent). Furthermore, users may also record their own voice, if they choose, and afterwards share their avatar/recording with others online. The same may also be done with other audio only recording apps, such as: Audacity, Voice Recorder, Vocaroo or Audioboo, which may also be shared online. Through these different apps learners may have access not only to other varieties/accents of English, but also have the opportunity to express themselves in English. As result, a greater awareness is promoted in terms of linguistic diversity and language production, instead of simply completing the listening exercises provided by course book publishers.

As for developing a more collaborative and communicative approach, this seems to be the area that deserves further attention and that is in line with developing a more ELF-aware perspective. EFL lessons are largely taught within a confined space with limited 'access' to the outside world, in which the learning process is rarely complemented through supplementary activities, and hardly ever is communication with others promoted. However, if communication in EFL classes is in fact a key issue, and if, at a broader educational level, so is developing twenty-first century skills (ANANIADOU \& CLARO, 2009), establishing intra- and international projects seems like the ideal solution 
to this issue. Projects not only promote learner autonomy, but also provide for chances to practice the language, give feedback, as well as share personal and cultural information (WARE et al., 2012, p. 75). At a European level, the e'Twinning platform has allowed for many teachers working in European schools (primary to secondary) to communicate, collaborate, develop projects, share and, feel like they are part of a community. This exchange between schools has obviously resulted in many positive outcomes not only for the teachers involved, but also for the students, who have the opportunity to learn about other places and new people, which otherwise would not be possible.

Seeing as physical mobility may be both difficult and expensive for many, the Internet has proven to be an excellent way of bridging the physical distance between schools. Many are the apps that allow for both direct and indirect communication/collaboration, hence, providing learners with the opportunity to engage in 'real' language production and interaction, by working together and commenting on each other's work.

In terms of indirect collaboration, there may be projects that involve learners in joint writing projects, where together, for instance, they build a common text, book or magazine that is afterwards share and published (either physically or online). By promoting such an activity, learners realize how things may be done differently, how people may have different points of views on a certain topic, how they may need to negotiate the content of their writing, or even edit their partner's work. Some websites/apps that may help to promote such projects include: MadMagz, BoomWriter, Pixton, Storyboard That, Google Drive or Dropbox.

For indirect oral communication, the process is also very similar, only in this particular situation, learners may present themselves or a given topic, either via audio or video recording, and afterwards receive written/audio feedback from colleagues in other schools or countries, hence allowing for communication to transcend the classroom walls. In this case, VoiceThread or Flipgrid, for instance, are two possibilities that allow learners to actually engage in language interaction.

In addition, there are other apps that permit both direct and indirect communication, depending on the situation. Furthermore, since smartphones and iPads/tablets have become a common object in the hands of many students, no longer do letters/emails need to be exchanged when having a pen pal abroad. Whatsapp, Viber, Facebook Messenger, Instagram, Skype, Face Time or Google Hangouts, for example, have contributed to making communication both faster and easier, allowing for written, audio and/or video chats. By using such apps, which are a part of students' everyday lives, they may become more actively engaged with the language, aware of how it is used differently by other people and how it is necessary to negotiate meaning, in order to avoid miscommunication. Moreover, since technology is an integral part of their lives, the likelihood of them using it outside the classroom is higher. 


\section{CONCLUDING REMARKS}

The age-old idea that English was spoken among NSs of the language and was learnt by others to communicate with them when going to the UK or USA, has long given way to a far more extensive reality. Considering the current global pervasiveness of the English language across many fields of knowledge, it is evident, nowadays, that most interactions take place among a variety of different speakers, both native and non-native. Though it is clear that English is spoken differently across the world, there seem to only exist minor hindrances, which do not impede the very essence of communication. Consciously or unconsciously, speakers automatically adapt to their interlocutors and negotiate meaning accordingly, either through gestures, facial expressions or paraphrasing, among other techniques. It is interesting, however, when learning a foreign language, these techniques seem to disappear and the objective single handedly becomes to be perfect and 'sound' like a NS, there being no place for faults or mistakes. The same is true for English, where Standard British or American English have traditionally been the key models to follow, and where grammatical correctness is emphasized.

Given the international spread of the language, it is crucial that ELT practices be rethought in light of the current reality. Along with them, teaching materials also need to be reconsidered, keeping in mind the linguistic and cultural diversity associated with English language use. Choosing, adapting or building teaching materials is an arduous task though for many teachers, as course books tend to provide all the necessary guidelines. The issue, however, is to try not to become a 'slave' of the course book, but to assume, instead, a more critical stance, in which the more advantageous or interesting aspects are worked on, while additional and complementary materials/activities could be added on to further explore the topics being dealt with. Richards reiterates this idea when he suggests that teachers need to learn how to not only analyze textbooks, but also develop their own materials: "Textbooks should be regarded as one of the many resources teachers can draw upon in creating effective lessons, but teachers need training and experience in adapting and modifying textbooks as well as in using authentic materials and in creating their own teaching materials" (RICHARDS, 2002, p. 6).

Keeping this in mind, EFL teachers should learn how to critically analyze and assess their teaching context and course books from early on, so pre-service teacher education seems like the ideal time and place for student teachers to undergo both a reflective and transformative change, and acquire as well the necessary skills and know-how to adapt their classes accordingly. For this, Bayyurt and Sifakis' three-stage model (2017) plays a central role, as student teachers go through the necessary steps to 1) gain a deeper understanding and broader perspective of the spread of the English language and its use, 2) realize how this can affect at a deeper level their teaching practices and ability to create their own ELF-aware materials, and 3) finally implement what they have learned and afterwards critically reflect on their experience.

Seeing as the development of teaching materials/activities may be more challenging, especially if they are to be more ELF-centered, several sources have been provided in the 
hope of facilitating teachers' tasks when building their own materials and exercises. These sources intend to: 1) broaden learners' access to a variety of different Englishes and cultures, demonstrating how English is used differently around the world, 2) emphasize the importance of establishing successful communication, both oral and written, and how this can be achieved, and 3) make the learning process more interesting and captivating, by using technology learners are familiar with, so that they may interact with other students in similar situations and continue using the language once outside the classroom.

For this, audiovisual sources were taken into account, such as examples of successful NNSs, songs, films and television programs, as well as a variety of Internet sources. In this case, examples of online archives, digital media and Web 2.0 tools were considered. As for the latter, examples of websites/apps for text-to-speech or audio recordings were given, as well as examples that establish both direct and indirect communication and collaboration. With these sources, teachers can develop an array of materials and activities that may help promote greater ELF-awareness within the class, by fostering learners' understanding and perception of the linguistic and cultural diversity inherent in most communicative interactions, either at a national, regional or international level.

If these issues are acquired and assimilated from early on in teacher education, a new generation of EFL teachers will emerge; a generation that is more conscious of the opportunities that the linguistic and cultural diversity associated with English may bring into the classroom; a generation that is also able to feel more confident, so to freely liberate themselves from the course book and create their own teaching materials, which will consequently also liberate their students. By doing so, both teachers and learners can engage at a deeper level with the language, by analyzing and reflecting how actual language is used and actually employing the language in 'real' communicative situations.

\section{REFERENCES}

ANANIADOU, K.; CLARO, M. $21^{\text {st }}$ century skills and competences for new millennium learners in OECD countries. EDU working paper no. 41. Organisation for Economic Co-operation and Development, 2009.

ARIKAN, A. Age, gender and social class in ELT coursebooks: a critical study. Hacettepe Universitesi Egitum Fakultesi Dergisi, v. 28, n. 1, p. 29-38, 2005.

BASABE, E. A. From de-Anglicization to internationalisation: cultural representations of the UK and the USA in global, adapted and local ELT textbooks in Argentina. Profile Issues in Teachers Professional Development, v. 7, n. 1, p. 59-75, 2006.

BAYYURT, Y.; SIFAKIS, N. C. Transforming into an ELF-aware teacher: an EFL teacher's reflective journey. In: BOWLES, H.; COGO, A. (Org.). International perspectives on teaching English as a Lingua Franca: pedagogical insights. London: Palgrave MacMillan, 2015. p. 117-135. 
BAYYURT, Y.; SIFAKIS, N. C. Foundations of an EIL-aware teacher education. In: MATSUDA, A. (Org.) Preparing teachers to teach English as an International Language. Bristol: Multilingual Matters, 2017. p. 3-18.

CAVALHEIRO, L. Reflections on ELT pedagogy: functioning and communicating in English. Sintagma, v. 25, p. 7-18, 2013.

CAVALHEIRO, L. English as a lingua franca: bridging the gap between theory and practice in English language teaching. (Doctoral Thesis in Applied Linguistics), University of Lisbon, Portugal, 2015.

CAVALHEIRO, L.; GUERRA, L. When the textbook is not enough: how to shape an ELF classroom?. In: SIFAKIS, N. C. \& TSANTILA, N. (Org.). ELF for EFL contexts. Bristol: Multilingual Matters, forthcoming.

DEWEY, M. English as a lingua franca: an empirical study of innovation in lexis and grammar. (Doctoral Thesis), King's College London, England, 2006.

DINH, T. N. Preparing preservice teachers with EIL/WE-oriented materials development. In: MATSUDA, A. (Org.) Preparing teachers to teach English as an International Language. Bristol: Multilingual Matters, 2017. p. 131-146.

FRIEDRICH, P.; MATSUDA, A. When five words are not enough: a conceptual and terminological discussion of English as a lingua franca. International Multilingual Reasearch Journal, v. 4, n. 1, p. 20-30, 2010.

JENKINS, J. The phonology of English as an international language. Oxford: Oxford University Press, 2000.

JENKINS, J. A sociolinguistically based, empirically researched pronunciation syllabus for English as an International Language. Applied Linguistics, v. 23, n. 1, p. 83-103, 2002.

JENKINS, J. English as a lingua franca from the classroom to the classroom. ELT Journal, v. 66, n. 4, p.486-494, 2012.

JENKINS, J.; COGO, A.; DEWEY, M. Review of developments in research into English as a Lingua Franca. Language Teaching, v. 44, n. 3, p. 81-315, 2011.

KACHRU, B. Standards, codification and sociolinguistic realm: The English language in the outer circle. In: QUIRK, R. \& WIDDOWSON, H. G. (Org.). English in the world: teaching and learning the language and literatures. Cambridge: Cambridge University Press, 1985. p. 11-30.

KACHRU, B. World Englishes and Culture Wars. In: KACHRU B., KACHRU, Y. \& NELSON, C. (Org.). Handbook of World Englishes. Malden: Blackwell, 2006. p. 446-471.

LOPRIORE, L.; VETTOREL, P. Promoting Awareness of Englishes and ELF in the English Language Classroom. In: BOWLES, H. and COGO, A. (Org.). International 
perspectives on English as a lingua franca: pedagogical insights. London: Palgrave Macmillan, 2015, p. 13-34.

MATSUDA, A. Teaching materials in EIL. In: ALSAGOFF, L., MCKAY, S.L., HU, G. \& RENEDY, W. A. (Org.). Principles and practices for teaching English as an international language. London: Routledge, 2012a. p. 168-185.

MATSUDA, A. Introduction Teaching English as an International Language. In: MATSUDA, A. (Org.). Principles and practices of teaching English as an International Language. Bristol, Buffalo \& Toronto: Multilingual Matters, 2012b. p. 1-14.

MATSUDA, A. Preparing teachers to teach English as an International Language. Bristol: Multilingual Matters, 2017.

MCKAY, S. L. Teaching English as an international language: rethinking goals and approaches. Oxford, Oxford University Press, 2002.

MCKAY, S. L.; BOKHORST-HENG, W. E. International English in its sociolinguistic contexts. New York \& London: Routledge, 2008.

RICHARDS, J. C. The role of textbooks in a language program. New Routes, v. 17. São Paulo, DISAL. p. 26-30, 2002.

RICHARDS, J.; FARRELL, T. Professional development for language teachers: strategies for teacher learning. Cambridge: Cambridge University Press, 2005.

SEIDLHOFER, B. Research perspectives on teaching English as a Lingua Franca. Annual Review of Applied Linguistics, v. 24, p. 209-239, 2004.

SEIDLHOFER, B. Understanding English as a Lingua Franca. Oxford: Oxford University Press, 2011.

SHARIFIAN, F. (Org.) English as an international language: perspectives and pedagogical issues. Bristol: Multilingual Matters, 2009.

SIFAKIS, N. Teacher education in the post-modern era: introducing a transformative dimension in the teaching of English as a lingua franca. In Selected Papers from the $18^{\text {th }}$ ISTAL, p. 345-353, 2009.

SIFAKIS, N. Towards a transformative ELF-aware education: Challenges and opportunities for teaching, learning and teacher education. Plenary talk presented at the $7^{\text {th }}$ International Conference of English as a Lingua Franca. September 4-6, 2014. Athens, Greece. Available at: https://www.youtube.com/watch?v=ovr95tQX8AI. Access on: 15 Oct. 2014.

SIQUEIRA, D. S. P. O papel do professor na desconstrução do "mundo plástico" do livro didático de LE. In: ASSIS-PETERSON, A. A. \& BARROS, S. M. (Org.). Formação crítica de professores de línguas: desejos e possibilidades. São Carlos (SP): Pedro \& João Editores, 2010, p. 225-253. 
SIQUEIRA, D. S. P. ELF and the plastic world of ELT materials. In: BAYYURT, Y. \& AKCAN, S. (Org.). Current perspectives on pedagogy for English as a lingua franca. Berlin: De Gruyter Mouton, 2015, p. 239-257.

VETTOREL, P.; LOPRIORE, L. Is there ELF in ELT course-books? Studies in Second Language Learning and Teaching, v. 3, n. 4, p. 483-504, 2013.

WARE, P.; WARE, P.; LIAW, M.-L.; WARSCHAUER, M. The use of digital media in teaching English as an international language. In: ALSAGOFF, L., MCKAY, S.L., HU, G. \& RENEDY, W. A. (Org.). Principles and practices for teaching English as an international language. London: Routledge, 2012. p. 67-84.

WENINGER, C; KISS, T. Culture in English as a foreign language (EFL) textbooks: a semiotic approach. TESOL Quarterly. v. 47, n. 4, p. 694-716, 2013.

WIDDOWSON, H. G. Aspects of language teaching. Oxford: Oxford University Press, 1990.

Recebido em: $15 / 08 / 2017$

Aprovado em: 26/11/2017

Publicado em: 30/12/2017 